FACTA UNIVERSITATIS

Series: Physical Education and Sport, Vol. 16, No 2, 2018, pp. 435 - 450

https://doi.org/10.22190/FUPES180604039M

Research article

\title{
EFFECTS OF A 12 WEEK RECREATIONAL FOOTBALL AND HIGH-INTENSITY INTERVAL TRAINING ON PHYSICAL FITNESS IN OVERWEIGHT CHILDREN
}

\author{
UDC 796.323.012.1-053. \\ 796.015 .54
}

\section{Nemanja Cvetković, Emilija Stojanović, Nenad Stojiljković, Dušan Nikolić, Zoran Milanović}

Faculty of Sport and Physical Education, University of Niš, Niš, Serbia

\begin{abstract}
The purpose of this study was to determine the effects of a 12 week recreational football and high-intensity interval training (HIIT) on physical fitness in overweight children. Forty-two overweight and obese boys aged 11-13 were randomly divided into three groups: HIIT group $(n=14)$, recreational football $(n=14)$ and a control group that attended regular physical education classes $(n=14)$. Physical fitness components were measured at baseline and after 12 weeks of training at the same time of the day and under similar conditions, including: countermovement jump (CMJ), sprint over 10 and 30 $m$, flexibility and biochemical parameters (leukocytes, erythrocytes, hemoglobin, glucose, total cholesterol, triglycerides). HIIT group increased explosive power of lower extremities by $7.16 \%$ (small ES), while the recreational football group recorded slightly less increase of $6.57 \%$ (small ES). HIIT led to a statistically significant increase ( $p<0.05$ ) in the number of erythrocytes in the blood (8.90\%). The recreational football program influenced the improvement of results in variables spreading lying on the back (6.21\%) and the number of erythrocytes ( $\uparrow 9.11 \%)$. Twelve-weeks of recreational football and HIIT can lead to positive changes in muscle fitness, flexibility and biochemical parameters in overweight and obese children. Compared to the experimental groups, the control group noted minor changes in the aforementioned variables, which indicates the lack of intensity of exercise programs in regular classes of physical education.
\end{abstract}

Key words: recreational soccer; interval training; obesity; fitness

Received June 4, 2018 / Accepted October 25, 2018

Corresponding author: Zoran Milanović

University of Niš, Faculty of Sport and Physical Education, Čarnojevića 10a, 18000 Niš, Serbia

Phone: +381 $18510900 \bullet$ E-mail: zoooro_85@yahoo.com 


\section{INTRODUCTION}

The number of obese children has increased dramatically throughout the world in the last fifty years, partly because of reduced physical activity, and partly because of an unhealthy diet (Styne, 2001; Ogden et al., 2006). Although regular physical activity protects against the onset of many diseases, some recent estimates state that the current level of youth activity does not meet the recommended level of exercise (Rajović, Berić, Bratić, Živković, \& Stojiljković, 2017; McLure, Summerbell, \& Reilly, 2009). Insufficient physical activity and the appearance of obesity are associated with all the risks of cardiovascular diseases (Skinner, Perrin, Moss, \& Skelton., 2015; McMurray \& Andersen, 2010), increasing the risk of premature mortality (Freedman, Mei, Srinivasan, Berenson, 2007). Based on the measurement and comparison of body mass index (BMI) over 128.9 million people from 200 different countries aged 5-12 years by Abarca-Gomez et al. (2017), it can be concluded that the average BMI value in the period 1975-2016 was on the rise. In 1975, the average BMI in the world in boys of the mentioned age was $16.8 \mathrm{~kg} / \mathrm{m}^{2}$, while BMI in girls was $17.2 \mathrm{~kg} / \mathrm{m}^{2}$. For every ten years, average BMI values were increased by $0.32 \mathrm{~kg} / \mathrm{m}^{2}$ for girls and $0.40 \mathrm{~kg} / \mathrm{m}^{2}$ for boys, which in 2016 led to an increase in BMI average value and it was $18.5 \mathrm{~kg} / \mathrm{m}^{2}$ for boys, while for girls BMI value was $18.6 \mathrm{~kg} / \mathrm{m}^{2}$. Exercise, as a very important tool in preserving health and preventing the onset of obesity (Panel, 1998), has proven to be very effective in weight reduction in a short period of time. Regular physical activity will lead to the preservation of the desired body weight over a long period of time (Pronk \& Wing, 1994).

Despite well-defined benefits from the influence of physical activity on overall health, children's school curriculum does not meet their basic needs for movement (Ekelund, Tomkinson, \& Armstrong, 2011). Sport's class and physical education should be used to spread awareness of the importance of sports and the promotion of sports in general (Sallis \& McKenzie, 1991). Unfortunately, in addition to its excellent position in the school schedule, we can conclude that the plan and program of sports and physical education is not adjusted in the best way in combating and preventing the appearance of obesity (Wang, Pereira, \& Mota, 2005; Human Services, 2000).

The program of high intensity interval training (HIIT) can lead to the improvement of the cardiorespiratory system in obese children in only 6-12 weeks of exercise (Lambrick, Westrupp, Kaufmann, Stoner, \& Faulkner, 2016; Saavedra, Escalante, \& Garcia-Hermoso, 2011), improve muscle blood flow (Tremblay, Simoneau \& Bouchard, 1994), decrease the BMI value (De Araujo et al., 2012) and can lead to the weight and visceral fat regulation. (Koubaa et al., 2013). All of the above results can be achieved in only 29 minutes which is the average time of the HIIT (García-Hermoso et al., 2016) compared to the forty-fiveminute traditional aerobic exercise of moderate intensity (Helgerud et al., 2007). In some studies, the program of HIIT, compared to the traditional aerobic exercise, recorded better results in improving the aerobic capacity and health of the healthy (Ramos, Dalleck, Tjonna, Beetham, \& Coombes, 2015) and obese people (Lunt et al., 2014). Meta-analysis of GarcíaHermoso et al. (2016) indicates that the high intensity interval training is more effective in reducing the diastolic blood pressure in children and adults (Bond, Hind, Williams, \& Barker, 2015) compared to other exercise programs. 
Recreational football proved to be an adequate tool in the fight against the prevention of obesity in children (Krustrup et al., 2014). Moreover, this type of physical activity is an appropriate alternative to continuous-practice exercises, such as: running, cycling, swimming or other activities that lead to the improvement of the cardiorespiratory system in obese children for a very short training time (Castagna et al., 2007). In addition to beneficial effects on the development of the cardiorespiratory system, recreational football favors the reduction of body fat (Nybo et al., 2010) and the oxidation of body fat (Krustrup et al., 2010b). Recreational football is characterized by a large number of turns, jumps, short sprints that favorably increase the muscle mass and the bone density of individuals (Krustrup, Rollo, Nielsen, \& Krustrup, 2007; Andersson, Ekblom, \& Krustrup, 2008). Also, recreational football should be used to promote health because of the high popularity in the world, a large number of motivational factors and the easiness of use.

Therefore the purpose of this study was to determine the effects of a 12 week recreational football and high-intensity interval training on physical fitness in overweight children.

\section{METHODS}

\section{Participants}

The total sample of participants consisted of 42 overweight and obese boys aged 1113 years. A detailed overview of selection of the subjects is shown in Figure 1. Inclusion criteria for participating in the study were: 1) boys 11-13 years of age; 2) BMI values belong to a group of overweight or obese boys according to classification by Cole et al. (2000); 3) do not suffer from any chronic disease; 4) they were not included in an organized form of physical activity at least six months before the start of the experimental treatment and do not have an organized form of training. The boys in control group do not participate in any additional forms of recreational physical exercise other than regular physical education classes. Criteria for exclusion from the study referred to the boys with respiratory and cardiovascular diseases, developmental disorders, boys with chronic illnesses and boys in the process of recovering from injuries or illnesses as well as boys who were involved in an organized physical exercise six months before the start of the study. The participants were randomly divided into three groups: the HIIT $(n=14)$, recreational football $(n=14)$ and a control group that attended regular classes in sports and physical education $(n=14)$. Prior to the start of the experiment, the written approval of their parents was requested in accordance with the Helsinki Declaration. Each parent of the participants, before the start of the research, gave a written consent in the name of his child to voluntarily enter the research. The participants were allowed to withdraw from the study at any time, if they wanted to. 


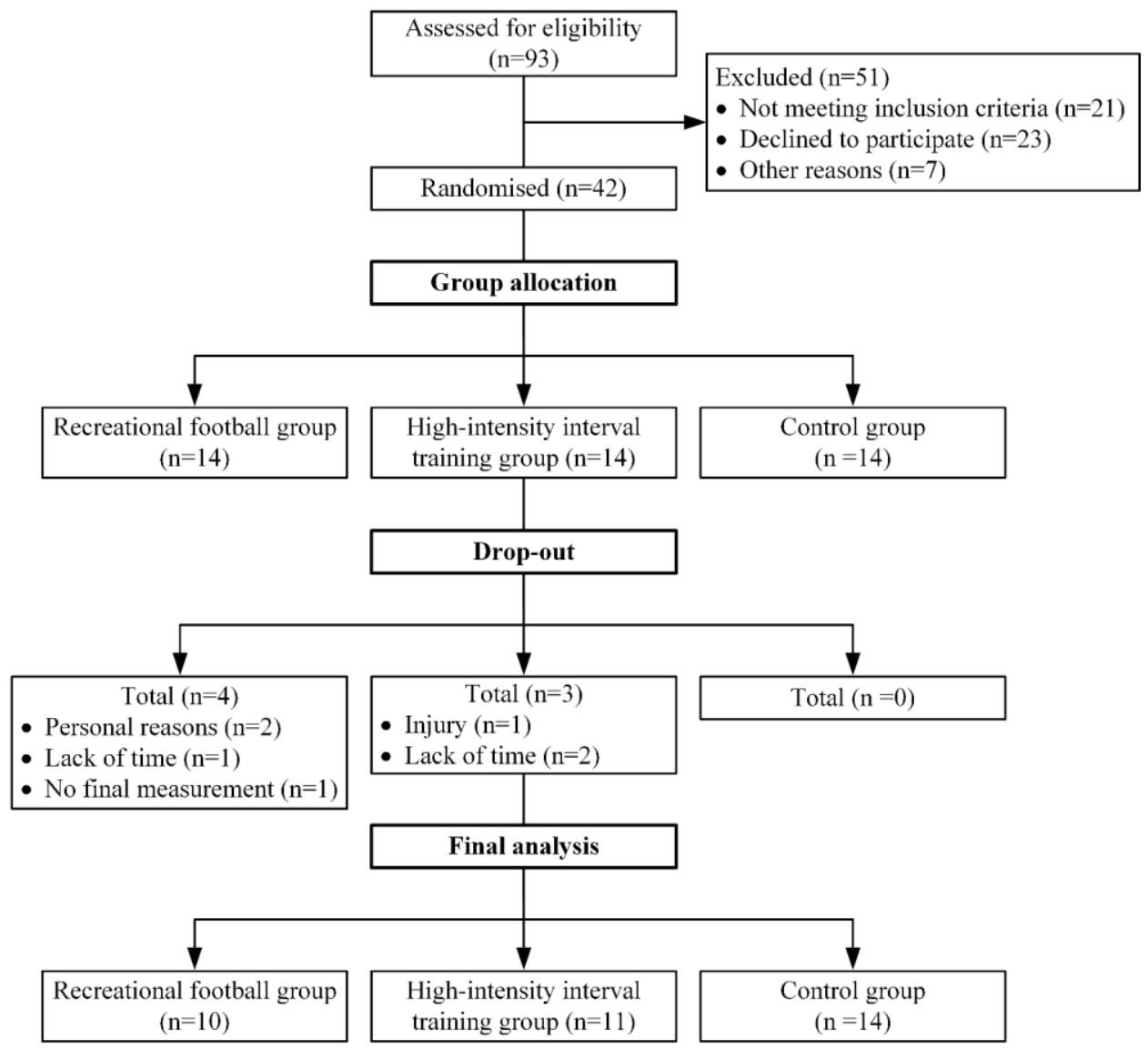

Fig. 1 Selection of participants, random distribution and final analysis.

\section{Procedures}

After the initial testing, the participants were randomly assigned to three groups: recreational football, HIIT group and control group, with 14 participants in each group. Physical fitness parameters were measured in all participants at baseline and final stage including: muscular fitness (squat jump, sprint $10 \mathrm{~m}$ and sprint $30 \mathrm{~m}$ ), flexibility (leg spreading lying on the back, flexibility of bending the body and flexibility of stretching the body) and biochemical parameters (leukocytes, erythrocytes, hemoglobin, glucose, cholesterol, triglycerides). During the experimental treatment, two boys left the group of recreational football for personal reasons, one boy gave up because of lack of time. In the group of the HIIT, three boys did not complete the experimental program (one boy gave up because of knee pain while two boys gave up because of lack of time). 


\section{Muscle fitness}

Countermovement jump (CMJ). The maximum vertical jump with the hands placed aside was measured using Optojump (Optojump, Microgate, Bolzano, Italy). Optojump measures the time spent in jumping and based on this, the jump strength with an accuracy of $0.1 \mathrm{~cm}$ is calculated indirectly. The participants had three attempts with a break of one minute between each attempt, and the best try was recorded.

Sprint over 10 and $30 \mathrm{~m}$. The test took place on a football field of 40 meters. Two sets of photo-stations were placed on the tenth and thirtieth meter from the starting line. The photo-stations were set at the height of the hip of the participants, and the distance between the photo-stations in pair is one hundred and twenty centimeters. At the starter sign, the subject starts and runs the indicated distance at the maximum speed. The test is completed after the participant performs the correct sprint. The break between the sprints takes about two minutes and the final result is the participant's best result expressed in seconds with an accuracy of 1/100.

\section{Flexibility}

Measuring of the lower back flexibility during the body bending. The participant is on the floor stretching his legs, while the pelvis should be placed in a stable position in order to avoid its inclination (leaning). The beginning of the measuring tape is placed on the last cervical vertebra S7 and the accompanying line to the level of the front lower thigh spine. The participant has two attempts to perform the body bending in the segment of the lower back to the first sign of resistance, and then the distance between the starting and the end point is recorded. The person in charge of measuring reads the result on the measuring tape expressed in centimeters and records a better result.

Measuring flexibility of the lower back during the body stretching. The subject is on the floor stretching his legs, while the pelvis should be placed in a stable position in order to avoid its inclination (leaning). The start of the measuring tape is placed on the last cervical vertebra S7 and the accompanying line up to the level of the front lower thigh spine. The participant has two attempts to perform the maximum body stretching in the segment of the lower back to the first sign of resistance, and then the distance between the starting and end point is recorded. The person in charge of measuring reads the result on the measuring tape expressed in centimeters and records a better result.

Leg spreading lying on the back. A barefoot respondent lying on his back is on a mat, his legs are stretched, lifted up and leaned against the wall. The subject is positioned so that the middle of his body coincides with the drawn line of the angle of $90^{\circ}$. At the sign of the measurer, the respondent maximally spreads his legs (leg spreading). After the respondent has reached the maximum range of movement, he retains the position until the measurer reads the result. When performing the test, the participant must not bend his legs in knees. The test is completed when the subject performs two correct leg spreads lying on his back. The break between two repetitions takes about ten seconds. The scorer reads the score on the angle under which each leg is located. After that, the result of the left leg is deducted from the achieved result of the right leg. The better achieved result is recorded as the final and is expressed in degrees (o). 


\section{Biochemical parameters}

A standard procedure for taking and analyzing the venous blood sample was used to evaluate biochemical parameters. The blood sample was taken between 7 a.m. and 9 a.m. in the morning at the Health Center in Pirot. The total amount of venous blood that was taken was five milliliters, which was sufficient for further analysis. The medical technician recorded the name and surname of the participants and the date of sampling before the blood was taken. Biochemical parameters for analysis were: Leukocytes, Erythrocytes, Hemoglobin, Glucose, Total cholesterol, Triglycerides.

\section{Training interventions}

Training intervention is described in details in previous study (Cvetković et al., 2018). The football training and HIIT groups were supervised by at least one of the investigators and performed three times per week. Football training was conducted outdoors on artificial grass and consisted of ordinary five- to seven-a-side matches with a relative pitch area of $80 \mathrm{~m} 2$ per player. Each training session lasted approximately $60 \mathrm{~min}$, including a 10min low-intensity warm-up followed by 4 x 8 -min periods of play interspersed with 2 min of passive rest and ending with a 10-min cool-down.

The HIIT programme consisted of three sets of high-intensity interval runs separated by 3 min of passive rest. Interval distances were individually adjusted according to each participant's maximal aerobic speed (MAS) determined by the Half-Cooper test, which was performed at baseline and repeated every fourth week in order to update the training speed. While training intensity was performed at $100 \%$ MAS, total training workload was calculated as arbitrary training units (ATU). ATU was calculated according to the following formula: ATU $=[[$ (work intensity + rest intensity $) / 2] \times$ number of repetitions $\mathrm{x}$ number of sets]. The distance for every participant was individually calculated by multiplying the achieved $100 \%$ MAS and work interval duration to obtain the same training intensity in every participant (e.g. distance run $=3.5 \mathrm{~m} / \mathrm{s}$ x $10 \mathrm{~s}=35 \mathrm{~m}$ ).

Participants in the control group continued their regular PE classes twice per week during the study period under the guidelines of the PE teacher according to curriculum for their age category. Both intervention groups completed the same PE classes in addition to their training.

\section{Statistical analysis}

Data analysis was performed using the Statistical Package for the Social Sciences (v13.0, SPSS Inc., Chicago, IL, USA). Basic descriptive parameters and normality of distribution were calculated for every variable. The differences between the initial and final measurements in both the experimental and control groups were determined by the T-test. Significance of the differences between the control and experimental groups at the initial and final measurements was determined by applying the multivariate analysis of variance (MANOVA) and two-way (group $\mathrm{x}$ time) univariate analysis of variance (ANOVA) with the application of Bonferoni's correction. The effect size was calculated for all variables. Statistical significance was set at $\mathrm{p}<0.05$. 


\section{RESULTS}

Normality of distribution was determined by Kolomogorov-Smirnov's test, while the Levens test did not show a violation of the homogeneity of the variance. The average intensity of training was different for all groups of participants. The highest average intensity of training was observed for HIIT with $80 \pm 3 \%$, followed by a group of recreational football with $75 \pm 2 \%$, and a control group with $68 \pm 2 \%$ of maximum heart rate (HRmax). The highest average calorie consumption per training was recorded by a group of recreational football with $496 \pm 43 \mathrm{kCal}$, followed by a group of high intensity interval training of $416 \pm$ $59 \mathrm{kCal}$ while the control group recorded the lowest calorie consumption with $320 \pm 32$ $\mathrm{kCcal}$ per class.

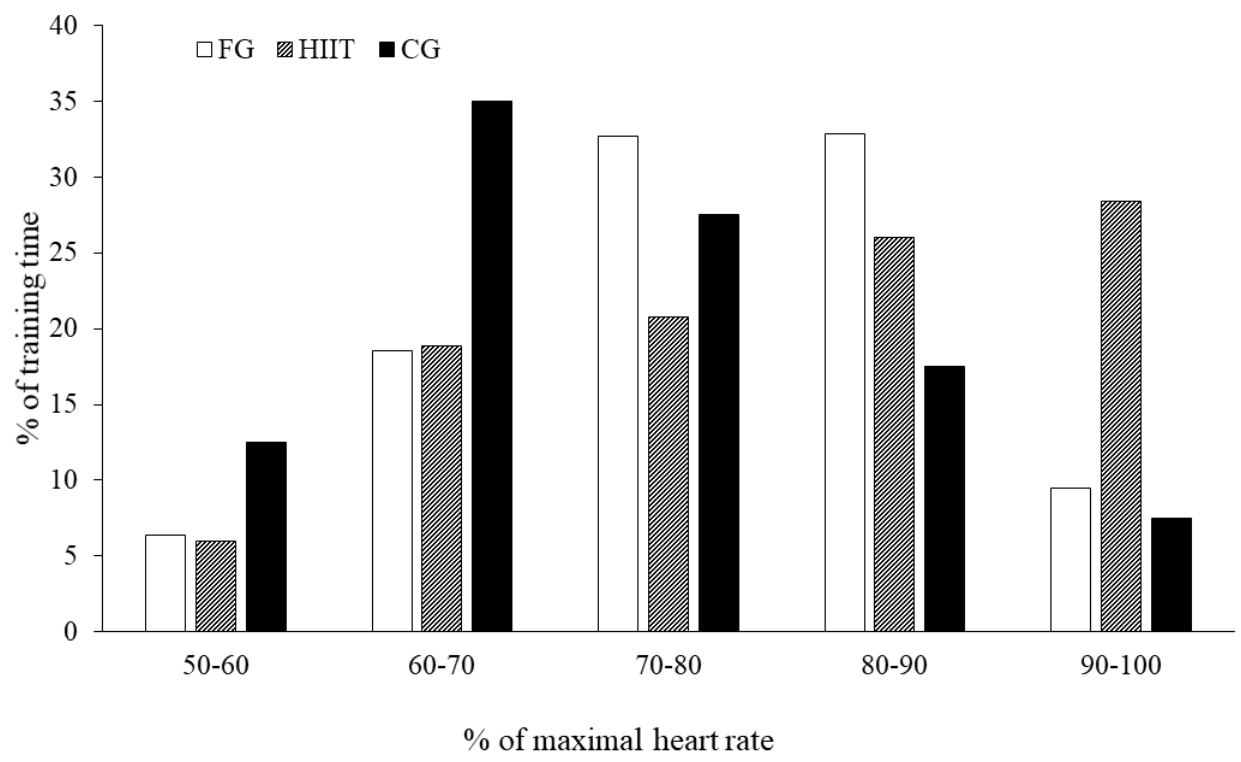

Fig. 2 Percentage of maximum heart rate; FG - football group; HIIT - high-intensity interval training group; $\mathrm{CG}$ - control group 
Table 1 Muscular fitness, flexibility and biochemical parameters of experimental and control groups, before and after a twelve-week exercise program

\begin{tabular}{|c|c|c|c|c|c|c|c|c|c|c|c|c|}
\hline & \multicolumn{2}{|c|}{$\begin{array}{l}\text { Football } \\
(n=10)\end{array}$} & \multirow[t]{2}{*}{$\begin{array}{c}\Delta \\
(\%)\end{array}$} & \multirow[t]{2}{*}{ ES } & \multicolumn{2}{|c|}{$\begin{array}{c}\text { HIIT } \\
(n=11)\end{array}$} & \multirow[t]{2}{*}{$\begin{array}{c}\Delta \\
(\%)\end{array}$} & \multirow[t]{2}{*}{ ES } & \multicolumn{2}{|c|}{$\begin{array}{l}\text { Control group } \\
(n=14)\end{array}$} & \multirow[t]{2}{*}{$\begin{array}{c}\Delta \\
(\%)\end{array}$} & \multirow[t]{2}{*}{ ES } \\
\hline & Initial & Final & & & Initial & Final & & & Initial & Final & & \\
\hline \multicolumn{13}{|l|}{ Muscle fitness } \\
\hline $\begin{array}{l}\text { Countermovement } \\
\text { jump }\end{array}$ & $\begin{array}{l}15.21 \\
\pm 3.21\end{array}$ & $\begin{array}{l}16.21 \\
\pm 2.66\end{array}$ & 6.57 & 0.34 & $\begin{array}{l}19.40 \\
\pm 4.27\end{array}$ & $\begin{array}{l}20.79 \\
\pm 4.57\end{array}$ & 7.16 & 0.31 & $\begin{array}{r}17.77 \\
\pm 5.53\end{array}$ & $\begin{array}{l}20.33 \\
\pm 5.63\end{array}$ & 14.36 & 0.46 \\
\hline Sprint $10 \mathrm{~m}$ & $\begin{array}{c}2.62 \\
\pm 0.23\end{array}$ & $\begin{array}{c}2.58 \\
\pm 0.19\end{array}$ & 21.17 & -0.21 & $\begin{array}{r}2.46 \\
\pm 0.17\end{array}$ & $\begin{array}{c}2.43 \\
\pm 0.17\end{array}$ & 8.85 & -0.17 & $\begin{array}{c}2.46 \\
\pm 0.23\end{array}$ & $\begin{array}{r}2.46 \\
\pm 0.21\end{array}$ & -0.07 & -0.01 \\
\hline Sprint $30 \mathrm{~m}$ & $\begin{array}{r}6.50 \\
\pm 0.65 \\
\end{array}$ & $\begin{array}{c}6.58 \\
\pm 0.56 \\
\end{array}$ & 14.91 & 0.13 & $\begin{array}{r}6.06 \\
\pm 0.53 \\
\end{array}$ & $\begin{array}{r}6.02 \\
\pm 0.51 \\
\end{array}$ & -0.39 & -0.06 & $\begin{array}{c}6.16 \\
\pm 0.68 \\
\end{array}$ & $\begin{array}{c}6.22 \\
\pm 0.75 \\
\end{array}$ & 0.98 & 0.08 \\
\hline \multicolumn{13}{|l|}{ Flexibility } \\
\hline $\begin{array}{l}\text { Leg spreading } \\
\text { lying on the back }\end{array}$ & $\begin{array}{c}84 \\
\pm 17.60\end{array}$ & $\begin{array}{c}106 \\
\pm 14.86^{\mathrm{a}}\end{array}$ & 30.86 & 1.35 & $\begin{array}{c}100 \\
\pm 12.04\end{array}$ & $\begin{array}{l}106.75 \\
\pm 10\end{array}$ & 5.50 & 0.61 & $\begin{array}{c}93.92 \\
\pm 16.31\end{array}$ & $\begin{array}{c}98.65 \\
\pm 10.63\end{array}$ & 2.43 & 0.34 \\
\hline $\begin{array}{l}\text { Flexibility of body } \\
\text { bending }\end{array}$ & $\begin{array}{c}48 \\
\pm 2.12^{\text {bc }}\end{array}$ & $\begin{array}{l}51.35 \\
\pm 3.04^{\mathrm{a}}\end{array}$ & 21.84 & 1.28 & $\begin{array}{l}51.82 \\
\pm 3.20\end{array}$ & $\begin{array}{l}52.10 \\
\pm 4.10\end{array}$ & 8.00 & 0.08 & $\begin{array}{l}51.42 \\
\pm 3.54\end{array}$ & $\begin{array}{l}52.38 \\
\pm 2.45\end{array}$ & 7.69 & 0.31 \\
\hline $\begin{array}{l}\text { Flexibility of body } \\
\text { stretching }\end{array}$ & $\begin{array}{c}45.1 \\
\pm 3.37^{\mathrm{c}}\end{array}$ & $\begin{array}{r}47.9 \\
\pm 3.39\end{array}$ & 26.19 & 0.83 & $\begin{array}{l}48.27 \\
\pm 2.81\end{array}$ & $\begin{array}{r}48.85 \\
\pm 3.72 \\
\end{array}$ & 6.75 & 0.18 & $\begin{array}{l}48.42 \\
\pm 3.04\end{array}$ & $\begin{array}{l}49.76 \\
\pm 2.46\end{array}$ & 5.03 & 0.48 \\
\hline \multicolumn{13}{|l|}{$\begin{array}{l}\text { Biochemical } \\
\text { parameters }\end{array}$} \\
\hline Leukocytes & $\begin{array}{c}7.91 \\
\pm 2.36\end{array}$ & $\begin{array}{r}7.59 \\
\pm 2.22\end{array}$ & -3.99 & -0.14 & $\begin{array}{c}7.06 \\
\pm 1.58\end{array}$ & $\begin{array}{c}6.92 \\
\pm 1.57\end{array}$ & -2.01 & -0.09 & $\begin{array}{r}7.16 \\
\pm 0.99\end{array}$ & $\begin{array}{c}6.72 \\
\pm 0.69\end{array}$ & -6.17 & -0.52 \\
\hline Erythrocytes & $\begin{array}{c}4.69 \\
\pm 0.20\end{array}$ & $\begin{array}{c}5.12 \\
\pm 0.26^{\mathrm{a}}\end{array}$ & 9.11 & 1.80 & $\begin{array}{c}4.79 \\
\pm 0.27\end{array}$ & $\begin{array}{c}5.21 \\
\pm 0.27^{\mathrm{d}}\end{array}$ & 8.90 & 1.58 & $\begin{array}{c}4.91 \\
\pm 0.30\end{array}$ & $\begin{array}{c}5.31 \\
\pm 0.35^{\mathrm{e}}\end{array}$ & 8.17 & 1.21 \\
\hline Hemoglobin & $\begin{array}{l}135.5 \\
\pm 6.91^{\mathrm{c}}\end{array}$ & $\begin{array}{l}134.7 \\
\pm 6.71\end{array}$ & -0.59 & -0.12 & $\begin{array}{c}143 \\
\pm 7.04\end{array}$ & $\begin{array}{c}139.18 \\
\pm 6.7\end{array}$ & -2.67 & -0.55 & $\begin{array}{l}148.84 \\
\pm 11.52\end{array}$ & $\begin{array}{l}143.07 \\
\pm 11.16\end{array}$ & -3.88 & -0.51 \\
\hline Glucose & $\begin{array}{c}5.02 \\
\pm 0.90\end{array}$ & $\begin{array}{c}4.94 \\
\pm 0.78\end{array}$ & -1.59 & -0.09 & $\begin{array}{c}5.14 \\
\pm 0.47\end{array}$ & $\begin{array}{c}5.01 \\
\pm 0.30\end{array}$ & -2.48 & -0.33 & $\begin{array}{c}5.27 \\
\pm 0.42\end{array}$ & $\begin{array}{c}4.96 \\
\pm 0.62\end{array}$ & -5.83 & -0.57 \\
\hline Cholesterol & $\begin{array}{c}4.07 \\
\pm 0.49\end{array}$ & $\begin{array}{c}4.29 \\
\pm 0.70\end{array}$ & 5.41 & 0.36 & $\begin{array}{c}3.93 \\
\pm 0.98\end{array}$ & $\begin{array}{c}4.42 \\
\pm 0.67\end{array}$ & 12.50 & 0.58 & $\begin{array}{c}4.24 \\
\pm 0.68\end{array}$ & $\begin{array}{c}4.26 \\
\pm 0.52\end{array}$ & 0.35 & 0.02 \\
\hline Triglycerides & $\begin{aligned} & 1.7 \\
& \pm 0.87\end{aligned}$ & $\begin{array}{c}1.51 \\
\pm 0.72\end{array}$ & -11.18 & -0.24 & $\begin{array}{c}1.55 \\
\pm 1.24\end{array}$ & $\begin{array}{r}1.10 \\
\pm 0.18\end{array}$ & -28.83 & -0.50 & $\begin{array}{c}1.51 \\
\pm 0.71\end{array}$ & $\begin{array}{r}1.16 \\
\pm 0.43\end{array}$ & -22.85 & -0.59 \\
\hline
\end{tabular}

ES - effect size; HIIT - high intensity interval training; $\Delta(\%)$ - percentage of change between initial and final measurement, a - statistically significant change between initial and final measurement in recreational football group $(\mathrm{p}<0.05), \mathrm{b}$ - statistically significant difference at initial measurement between recreational football and HIIT group $(\mathrm{p}<0.05), \mathrm{c}$ - statistically significant difference at initial measurement between recreational football and the control group $(\mathrm{r}<0.05), \mathrm{d}$ - statistically significant change between initial and final measurements in HIIT $(\mathrm{p}<0.05), e-$ statistically significant changes between initial and final measurements in control group $(\mathrm{p}<0.05)$.

\section{Muscle fitness}

Results showed that CMJ did not show significant differences among groups on the initial measurement $(\mathrm{p}>0.05)$. After the realized experimental treatment compared to the initial and the final measurement, no statistically significant change was recorded $(\mathrm{p}>$ 0.05 ) in all groups (Table 1). During the final measurement, no statistically significant difference was found between the groups. HIIT showed a slight increase in the strength at the final measurement compared to initial $(7.16 \%$, ES $=0.31$, small), slightly less progress was made by the group of recreational football $(6.57 \%, \mathrm{ES}=0.34$, small), while the control group achieved the highest percentage of progress $(14.36 \%, \mathrm{ES}=0.46$, small). At the final measurement, no statistically significant change $(p>0.05)$ was recorded 
between the experimental and control group in the $10 \mathrm{~m}$ sprint. The highest percentage of decrease was observed in HIIT group $(-2.13 \%,-0.21$ small), followed by the group of recreational football $(-0.97 \%, \mathrm{ES}=-0.17$, trivial $)$ and as the last, control group $(-0.07 \%$, $\mathrm{ES}=-0.01$, trivial). Also, no statistically significant difference $(\mathrm{p}>0.05)$ was recorded in the $30 \mathrm{~m}$ sprint.

\section{Flexibility}

The group of recreational football achieved the highest improvement after 12 weeks experimental program in the leg spreading lying on the back $(26.19 \%$, ES $=1.35$, very large), which is statistically significant $(\mathrm{r}<0.05)$, while the moderate increase was noted in HIIT $(6.75 \%, \mathrm{ES}=0.61$, moderate) and small in control group $(5.03 \%, \mathrm{ES}=0.34$, small). After the realized experimental treatment of 12 weeks, compared to the initial and final measurements, only the exercise program of the group of recreational football led to statistically significant changes $(6.98 \%, \mathrm{ES}=1.28$, very large) and achieving better results on the final measurement, which as a result had better flexibility of the spinal column ( $\mathrm{p}>$ $0.05)$. The control group recorded slightly less changes in the final testing $(5.03 \%, \mathrm{ES}=$ 0.31 , small) while the trivial change was recorded by a group of HIIT $(0.54 \%$, ES $=0.08$, trivial). The final measurement did not show statistically significant differences between groups. In the variable Flexibility of body stretching, statistically significant differences were observed on the initial measurement between the group of recreational football and the control group $(p<0.05)$, while no statistically significant change was recorded nor the difference between the groups at the final measurement. Large increase was made by the group of recreational football $(6.21 \%, \mathrm{ES}=0.83$, large $)$, trivial by the group of the HIIT $(1.20 \%, \mathrm{ES}=0.18$, trivial $)$ and a small in control group $(2.77 \%, \mathrm{ES}=0.48$, small $)$.

\section{Biochemical parameters}

On the basis of the obtained results, there was no statistically significant difference ( $\mathrm{p}$ > 0.05) among groups at the initial measurement in variables: Leukocytes, Glucose, Cholesterol, and Triglycerides. Also, in the mentioned variables there were no statistically significant difference at the final measurements between experimental and control groups. Compared to initial, all three groups recorded a statistically significant increase in the number of Erythrocytes in the blood $(\mathrm{p}<0.05)$ at final measurement (Table 1). The highest increase was recorded by the group of recreational football $(9.11 \%, \mathrm{ES}=1.80$, very large) followed by the group of HIIT $(8.90 \% \mathrm{ES}=1.58$, very large) and with the least percentage of change, the control group $(8.17 \%, \mathrm{ES}=1.21$, very large). A statistically significant difference in the initial testing was recorded in the variable Hemoglobin between the group of recreational football and the control group, while no significant change was observed in the final test ( $p>0.05)$. In percentage, the highest decrease of Hemoglobin was recorded by the group of recreational football $(-3.88 \%, \mathrm{ES}=-0.12$, trivial), while the HIIT group ($2.67 \%, \mathrm{ES}=-0.55$, moderate $)$ and the control group $(-0.59 \% \mathrm{ES}=-0.51$, moderate $)$ had a moderate changes. 


\section{DISCUSSION}

This study was aimed at determining the effect of a twelve-week of HIIT and recreational football on the parameters of muscular fitness, flexibility and biochemical parameters of the obese and overweight boys aged 11-13 years. We have determined which one of these two exercise programs leads to major changes in obese and overweight boys and how much the effects of these exercise programs differ from the effects achieved in physical education class. The recreational football program proved to be more effective in improving the parameters for assessing flexibility compared to other groups, while the differences in the improvement of parameters for the evaluation of biochemical parameters are trivial. Results showed that HIIT led to a statistically significant increase in the number of Erythrocytes in the blood $(\uparrow 8.90 \%)$. The recreational football program influenced the improvement of results in variables: Spreading lying on the back $(\uparrow 6.21 \%)$ and the number of Erythrocytes $(\uparrow 9.11 \%)$.

\section{Muscle fitness}

Regular physical activity leads to an increase in cardiorespiratory and muscular fitness, which together enables the muscle to continuously perform the movement without fatigue (Wilmore \& Costill, 1994). The increase in muscular fitness caused by exercise results in a better basal metabolism or burning of a higher percentage of fat during training and rest (Kriketos, Sharp, Seagle, Peters, \& Hill, 2000), improving speed and agility (Jackson, 2004), which is very important considering that the muscle mass decreases with the aging process. The developed muscular fitness makes it easier for people to perform the daily physical activities. On the other hand, the constant maintenance of muscular fitness is necessary in order to avoid and prevent injury. The developed muscular fitness helps the proper keeping of the body and prevents the appearance of deformities of the spinal column and flat feet which are very present in children due to insufficient movement and exercise.

HIIT and recreational football influenced favorably and contributed to the increase in the muscle fitness of experimental groups. In the CMJ, a similar progress of experimental groups was observed where, in the HIIT, the explosive power of lower extremities was increased by $7.16 \%$ (small ES), while the recreational football group recorded slightly less increase of $6.57 \%$ (small ES). Study of Buchan et al. (2013), which applied the training program of the highly intensive interval training, records the achievement of better results on the final measurement in CMJ compared to the results in this study. The training program of recreational football proved to be effective in increasing the explosive power of the lower extremities, as confirmed by previous studies conducted with the obese children (Seabra et al., 2016a; Seabra et al., 2016b). This program also proved to be effective for women (Helge et al., 2010) and the elderly (Andersen, Schmidt, Pedersen, Krustrup, \& Bangsbo, 2016; Sundrstrup et al., 2016) where the results achieved were less significant than the results obtained in our study.

Numerous repetitions of the run-in sections, which were individually dosed for each respondent during training and the entire experimental treatment with the maximum intensity in HIIT group, contributed to achieving a better result of $-1.22 \%$ in the sprint at 10 meters at the final measurement. Its effectiveness was also confirmed in boys aged 16 years with a similar exercise program (Buchan et al., 2013). Recreational football playing in the field of approximate dimensions of 40x20 meters with 10-14 players is characterized by high intensity of the game where more than $20 \%$ of the total time spent belongs to activities with 
an intensity of over $80 \%$ HRmax. Short sprints without a ball with the goal of "opening" and creating better position to give the player a ball, sprints with a ball in order to dribble the opposing player and gain an advantage in the attack, are some of the reasons for achieving a better result with $-1.74 \%$ in the final measuring in comparison with the group of HIIT in 10 $\mathrm{m}$ sprint. Interestingly, HIIT group made progress for $-0.52 \%$ in the sprint at 30 meters, while the participants from the group of recreational football recorded a worse time, an increase of $1.25 \%$ on the final measurement. Running the section during the training program of HIIT group ranged from 20 meters in the first to 60 meters in the third month of training. Adaptation to running these distances is one of the reasons why the group of HIIT achieved better results at the final measurement compared to the group of recreational football in sprint at 30 meters. The constant use of the same muscle groups, the body's habit of motoring and the increase in the strength of these muscle groups is the reason why the participants of this group achieved better results on the final measurement. Compared with high-intensity interval training, the group that practiced recreational football was not in the position to exert sprinting more than 20 to 30 meters because the dimensions of the filed (the total length of the field is 40 meters) did not allow it, and therefore they have achieved slightly worse results in sprint at 30 meters.

The control group achieved a percentage improvement in the final measurement on CMJ (14.36\%, small ES), which is significantly higher compared to the result of HIIT (7.16\%) and the group of recreational football $(6.57 \%)$. The control group recorded non-significant increase in the variable $10 \mathrm{~m}$ sprint $(-0.07 \%$, trivial ES), and a worse result in a 30 -meter sprint variable ( $0.98 \%$, trivial ES) makes them lesser compared to the experimental groups.

\section{Flexibility}

Flexibility can be developed at all stages, it only requires an individual access to each participant (Kostić, 2009). Moreover, flexibility is a very important ability in achieving better results in sports. A greater flexibility in joints allows a greater amplitude of movements and more regular performing of numerous exercises, increasing the resistance of muscles on potential numerous injuries (Church, Wiggins, Moode, \& Crist, 2001). A poor or insufficient movement of tendons, back and hips is associated with difficulty in performing everyday motor activities (Cornbleet \& Woolsey, 1996), which in obese boys can be reflected on activities that directly affect their quality of life: getting dressed, putting on socks, sneakers, shoes or tying shoelaces.

During both experimental programs, some of the exercises at the beginning of the training were the dynamic stretching exercises, while the boys at the end of the training performed the static stretching exercises. Both experimental groups have made progress on flexibility assessment tests. The recreational football group achieved a statistically significant improvement in the parameter measuring the flexibility of the lower back in bending of the body with $26.19 \%$ (a very large ES), whereas HIIT recorded a progress of $6.75 \%$ (trivial ES) as a consequence of a greater presence of movements with a higher amplitude during recreational football compared to running. The recreational football group also achieved better results in the flexibility of the lower back for stretching of the body with a percentage of progress in the final measurement of $6.98 \%$ (large ES), in contrast to the achieved results of HIIT group that has progressed only $12.54 \%$ (trivial ES). The obtained difference in favor of the group which had followed the recreational football was achieved 
due to a greater number of direction changes in the course of the game (Pedersen, Randers, Scott, \& Krustrup, 2009), such as different dribbles in attack and changes of direction with different dynamics and intensity. The other reason are defense movements where the focus of the body is constantly changing in order to prevent the opposing player from penetrating and endangering the goal (Pedersen et al., 2009; Randers, Nielsen, Krustrup, Sundstrup, \& Jakobsen, 2010b). The adductors of muscles of the lower extremities are more engaged during a football game than in straight line racing. This group of muscles is constantly engaged in playing at shorter and longer distances with different impacts on the ball, as well as when shooting at the goal. The performance of specific kicks in football such as volley kicks at the frontal and sagittal levels also contributes to the development of higher mobility. The performance of these kicks requires the involvement of the adductors of muscles of the lower extremities, which results in stretching of the muscles.

\section{Biochemical parameters}

A significant indicator of the state of the organism, besides various motoric tests and tests for evaluation of the cardiorespiratory system, are the biochemical parameters. Based on the individual biochemical parameters, it can be determined whether the health of a person is endangered and what measures should be taken to eliminate and prevent the unwanted consequences (Colosia, Palencia, \& Khan, 2013). A chronic increase in blood glucose levels, low level of fitness and low level of physical activity, as well as obesity, are associated with type 2 diabetes and a high mortality rate (Wei, Gibbons, Kampert, Nichaman, \& Blair 2000). Physical exercise has many times been proved to be good in improving muscle function and beneficial for regulating biochemical parameters in the organism (Holten et al., 2004).

The exercise program of the experimental groups proved to be appropriate in improving biochemical parameters. A group of HIIT recorded a statistically significant change-an increase in the number of erythrocytes in the final measurement by $8.90 \%$ (very large ES) compared to the initial measurement. Based on the results obtained, we can see how the body adjusts to the efforts. The recreational football group recorded statistically significant changes in the increase of the number of erythrocytes in the final measurement, with an increase of $9.11 \%$ (very large ES). If we compare the results obtained between the experimental groups, we will notice that the recreational football program has somewhat better results than HIIT. In addition to the increase in erythrocytes, in percentage, both experimental groups recorded a decrease in the hemoglobin levels. The decrease in the hemoglobin levels is slightly higher in the group of highly intensive interval training for $2.67 \%$ than in the group of recreational football for $-0.59 \%$.

Both experimental programs recorded a decrease in glucose in the final measurement. The results of this study coincide with the results of Randers et al. (2010a) who applied the recreational football program to its participants for 12-58 weeks. The recreational football program contributed to an increase in blood glucose levels, contrary to the results of this study, in middle-aged subjects with the same intensity and duration (Randers et al., 2012), as well as in the middle-aged women whose experimental treatment lasted for 52 weeks (Krustrup et al., 2017). HIIT group recorded a percentage-doubled increase in the blood cholesterol levels by $12.50 \%$ (moderate ES) as opposed to the group of recreational football by $5.41 \%$ (small ES). Contrary to the results obtained in this study, studies that conducted 
the program of recreational football in the same duration as in this study showed a decrease in the total cholesterol levels (Krustrup et al., 2010; Mohr et al., 2014), while some studies did not record changes in their researches (Barene et al., 2014; Randers et al., 2010; Krustrup et al., 2017). HIIT proved to be favorable in reducing the triglyceride level by $28.83 \%$ (moderate ES), while recreational football recorded a decrease in the final measurement by $11.18 \%$ (small ES). If we compare the recreational football program in this study with other studies that had a similar program of exercise with different groups of subjects and duration of the study (Mohr et al., 2014; Randers et al., 2010; Krustrup et al., 2017), we can conclude that the program of this study proved to be far more efficient. A 40week study did not record changes in the triglyceride level (Barene, Krustrup, Jackman, Brekke, \& Holtermann, 2014), while the recreational football program for twelve weeks with a group of middle-aged subjects recorded an increase in the cholesterol level (Randers et al., 2012).

\section{CONCLUSION}

After obtaining the results of a twelve-week experimental program of exercise in this study, we can conclude that the recreational football and HIIT can lead to positive changes in muscle fitness, flexibility and biochemical parameters. Compared with the experimental groups, the control group noted minor changes in the aforementioned variables, which indicates the lack of intensity of exercise programs in regular classes of physical education.

\section{REFERENCES}

Abarca-Gómez, L., Abdeen, Z.A., Hamid, Z.A., Abu-Rmeileh, N.M., Acosta-Cazares, B., Acuin, C., et al. (2017). Worldwide trends in body-mass index, underweight, overweight, and obesity from 1975 to 2016: a pooled analysis of 2416 population-based measurement studies in 128.9 million children, adolescents, and adults. The Lancet, 390(10113), 2627-2642.

Andersson, H., Ekblom, B., \& Krustrup, P. (2008). Elite football on artificial turf versus natural grass: movement patterns, technical standards, and player impressions. Journal of Sports Sciences, 26(2), 113-122.

Andersen, T.R., Schmidt, J.F., Pedersen, M.T., Krustrup, P., \& Bangsbo, J. (2016). The Effects of 52 weeks of soccer or resistance training on body composition and muscle function in+ 65 -year-old healthy males-a randomized controlled trial. PloS One, 11(2), e0148236.

De Araujo, A.C.C., Roschel, H., Picanço, A.R., do Prado, D.M.L., Villares, S.M.F., de Sa Pinto, A.L., et al. (2012). Similar health benefits of endurance and high-intensity interval training in obese children. Plos One, 7(8), e42747.

Barene, S., Krustrup, P., Jackman, S.R., Brekke, O.L., \& Holtermann, A. (2014). Do soccer and Zumba exercise improve fitness and indicators of health among female hospital employees? A 12-week RCT. Scandinavian Journal of Medicine and Science in Sports, 24(6), 990-999.

Bond, B., Hind, S., Williams, C.A., \& Barker, A.R. (2015). The acute effect of exercise intensity on vascular function in adolescents. Medicine and Science in Sport and Exercise, 42(12), 2628-2635.

Buchan, D.S., Ollis, S., Young, J.D., Cooper, S.M., Shield, J.P., \& Baker, J.S. (2013). High intensity interval running enhances measures of physical fitness but not metabolic measures of cardiovascular disease risk in healthy adolescents. BMC Public Health, 13, 498.

Castagna, C., Belardinelli, R., Impellizzeri, F. M., Abt, G. A., Coutts, A. J., \& D’Ottavio, S. (2007). Cardiovascular responses during recreational 5-a-side indoor-soccer. Journal of Science and Medicine in Sport, 10(2), 89-95.

Church, J.B., Wiggins, M.S., Moode, F.M., \& Crist, R. (2001). Effect of warm-up and flexibility treatments on vertical jump performance. The Journal of Strength and Conditioning Research, 15(3), 332-336. 
Cole, T.J., Bellizzi, M.C., Flegal, K.M., \& Dietz, W.H. (2000). Establishing a standard definition for child overweight and obesity worldwide: international survey. British Medical Journal, 320(7244), 1240.

Cornbleet, S.L., \& Woolsey, N.B. (1996). Assessment of hamstring muscle length in school-aged children using the sit-and-reach test and the inclinometer measure of hip joint angle. Physical Therapy, 76(8), 850-855.

Colosia, A. D., Palencia, R., \& Khan, S. (2013). Prevalence of hypertension and obesity in patients with type 2 diabetes mellitus in observational studies: a systematic literature review. Diabetes, Metabolic Syndrome and Obesity: Targets and Therapy, 6, 327-338.

Cvetković, N., Stojanović, E., Stojiljković, N., Nikolić, D., Scanlan, T.A., \& Milanović, Z. (2018). Exercise training in overweight and obese children: recreational football and high-intensity interval training provide similar benefits to physical fitness. Scandinavian Journal of Medicine and Science in Sports, 28(1), 18-32.

De Araujo, A.C.C., Roschel, H., Picanço, A.R., do Prado, D.M.L., Villares, S.M.F., de Sá Pinto, A.L., \& Gualano, B. (2012). Similar health benefits of endurance and high-intensity interval training in obese children. PloS One, 7(8), e42747.

Ekelund, U., Tomkinson, G., \& Armstrong, N. (2011). What proportion of youth are physically active? Measurement issues, levels and recent time trends. British Journal of Sports Medicine, 45(11), 859-865.

Freedman, D.S., Mei, Z., Srinivasan, S.R., Berenson, G.S., \& Dietz, W.H. (2007). Cardiovascular risk factors and excess adiposity among overweight children and adolescents: the Bogalusa Heart Study. The Journal of Pediatrics, 150(1), 12-17.

García-Hermoso, A., Cerrillo-Urbina, A. J., Herrera-Valenzuela, T., Cristi-Montero, C., Saavedra, J. M., \& Martínez-Vizcaíno, V. (2016). Is high-intensity interval training more effective on improving cardiometabolic risk and aerobic capacity than other forms of exercise in overweight and obese youth? A meta-analysis. Obesity Reviews, 17(6), 531-540.

Jackson, A.W. (2004). Physical activity for health and fitness. Human Kinetics Publishers.

Human Services (2000). Healthy people 2010 (Vol. 1). US Department of Health and Human Services. Retrived on September 05 at the World Wide Web: https://www.cdc.gov/nchs/healthy_people/hp2010.htm

Helgerud, J., Høydal, K., Wang, E., Karlsen, T., Berg, P., Bjerkaas, M., \& Hoff, J. (2007). Aerobic highintensity intervals improve VO2max more than moderate training. Medicine and Science in Sport and Exercise, 39(4), 665-671.

Helge, E. W., Aagaard, P., Jakobsen, M. D., Sundstrup, E., Randers, M. B., Karlsson, M. K., et al. (2010). Recreational football training decreases risk factors for bone fractures in untrained premenopausal women. Scandinavian Journal of Medicine and Science in Sports, 20(s1), 31-39.

Holten, M.K., Zacho, M., Gaster, M., Juel, C., Wojtaszewski, J.F., \& Dela, F. (2004). Strength training increases insulin-mediated glucose uptake, GLUT4 content, and insulin signaling in skeletal muscle in patients with type 2 diabetes. Diabetes, 53(2), 294-305.

Kriketos, A.D., Sharp, T.A., Seagle, H.M., Peters, J.C., \& Hill, J.O. (2000). Effects of aerobic fitness on fat oxidation and body fatness. Medicine and Science in Sports and Exercise, 32(4), 805-811.

Koubaa, A., Trabelsi, H., Masmoudi, L., Elloumi, M., Sahnoun, Z., Zeghal, K. M., \& Hakim, A. (2013). Effect of Intermittent and continuous training on body composition cardio-respiratory fitness and lipid profile in obese adolescents. International Journal of Pharmacy and Biological Sciences, 3(2), 31-37.

Kostić, R. (2009). Basic fitness components. Nis: Faculty of Sport and Physical education.

Krustrup, B.R., Rollo, I., Nielsen, J.N., \& Krustrup, P. (2007). Effects on training status and health profile of prolonged participation in recreational football: heart rate response to recreational football training and match-play. Journal of Sports Science \& Medicine, 6(10), 116-117.

Krustrup, P., Christensen, J. F., Randers, M. B., Pedersen, H., Sundstrup, E., Jakobsen, M. D., et al. (2010). Muscle adaptations and performance enhancements of soccer training for untrained men. European Journal of Applied Physiology, 108(6), 1247-1258.

Krustrup, P., Hansen, P. R., Nielsen, C. M., Larsen, M. N., Randers, M. B., Manniche, V., et al. (2014). Structural and functional cardiac adaptations to a 10-week school-based football intervention for 910-year-old children. Scandinavian Journal of Medicine and Science in Sports, 24(S1), 4-9.

Krustrup, P., Skoradal, M. B., Randers, M. B., Weihe, P., Uth, J., Mortensen, J., et al. (2017). Broad-spectrum health improvements with one year of soccer training in inactive mildly hypertensive middle-aged women. Scandinavian Journal of Medicine and Science in Sports, 27(12), 1893-1901.

Lambrick, D., Westrupp, N., Kaufmann, S., Stoner, L., \& Faulkner, J. (2016). The effectiveness of a highintensity games intervention on improving indices of health in young children. Journal of Sports Sciences, 34(3), 190-198. 
Lunt, H., Draper, N., Marshall, H.C., Logan, F.J., Hamlin, M.J., Shearman, J.P., et al. (2014). High intensity interval training in a real world setting: a randomized controlled feasibility study in overweight inactive adults, measuring change in maximal oxygen uptake. PloS One, 9(1), e83256.

McLure, S.A., Summerbell, C.D., \& Reilly, J. J. (2009). Objectively measured habitual physical activity in a highly obesogenic environment. Child: Care, Health and Development, 35(3), 369-375.

McMurray, R.G., \& Andersen, L. B. (2010). The influence of exercise on metabolic syndrome in youth: A review. American Journal of Lifestyle Medicine, 4(2), 176-186.

Mohr, M., Lindenskov, A., Holm, P. M., Nielsen, H. P., Mortensen, J., Weihe, P., et al. (2014). Football training improves cardiovascular health profile in sedentary, premenopausal hypertensive women. Scandinavian Journal of Medicine and Science in Sports, 24(S1), 36-42.

Nybo, L., Sundstrup, E., Jakobsen, M. D., Mohr, M., Hornstrup, T., Simonsen, L., et al. (2010). High-intensity training versus traditional exercise interventions for promoting health. Medicine and Science in Sports and Exercise, 42(10), 1951-1958.

Ogden, C.L., Carroll, M.D., Curtin, L.R., McDowell, M.A., Tabak, C.J., \& Flegal, K. M. (2006). Prevalence of overweight and obesity in the United States, 1999-2004. Journal of the American Medical Association, 295(13), $1549-1555$.

Panel, N.O.E.I.E. (1998). Clinical guidelines on the identification, evaluation, and treatment of overweight and obesity in adults: the evidence report (No. 98). National Heart, Lung, and Blood Institute.

Pedersen, M. T., Randers, M. B., Skotte, J. H., \& Krustrup, P. (2009). Recreational soccer can improve the reflex response to sudden trunk loading among untrained women. The Journal of Strength and Conditioning Research, 23(9), 2621-2626.

Pronk, N.P., \& Wing, R.R. (1994). Physical activity and long-term maintenance of weight loss. Obesity Research, 2(6), 587-599.

Rajović, R., Berić, D., Bratić, M., Živković, M., \& Stojiljković, N. (2017). Effects of an "NTC" exercise program on the development of motor skills in preschool children. Facta Universitatis, Series Physical Education and Sport, 14(3), 315-329.

Ramos, J.S., Dalleck, L.C., Tjonna, A.E., Beetham, K.S., \& Coombes, J.S. (2015). The impact of high-intensity interval training versus moderate-intensity continuous training on vascular function: a systematic review and meta-analysis. Sports Medicine, 45(5), 679-692.

Randers, M. B., Nielsen, J. J., Krustrup, B. R., Sundstrup, E., Jakobsen, M. D., Nybo, L., et al. (2010a). Positive performance and health effects of a football training program over 12 weeks can be maintained over a 1-year period with reduced training frequency. Scandinavian Journal of Medicine and Science in Sports, 20(s1), 80-89.

Randers, M.B., Nielsen, J. J., Krustrup, B.R., Sundstrup, E., Jakobsen, M.D. (2010b). Positive performance and health effects of a football training program over 12 weeks can be maintained over a 1-year period with reduced training frequency. Scandinavian Journal of Medicine and Science in Sports, 20(S1), 80-89.

Randers, M.B., Petersen, J., Andersen, L.J., Krustrup, B. R., Hornstrup, T., Nielsen, J.J., et al. (2012). Shortterm street soccer improves fitness and cardiovascular health status of homeless men. European Journal of Applied Physiology, 112(6), 2097-2106.

Sallis, J.F., \& McKenzie, T.L. (1991). Physical education's role in public health. Research Quarterly for Exercise and Sport, 62(2), 124-137.

Saavedra, J.M., Escalante, Y., \& Garcia-Hermoso, A. (2011). Improvement of aerobic fitness in obese children: a meta-analysis. Pediatric Obesity, 6(3-4), 169-177.

Seabra, A., Katzmarzyk, P., Carvalho, M. J., Seabra, A., Coelho-E-Silva, M., Abreu, S., et al. (2016a). Effects of 6-month soccer and traditional physical activity programmes on body composition, cardiometabolic risk factors, inflammatory, oxidative stress markers and cardiorespiratory fitness in obese boys. Journal of Sports Sciences, 34(19), 1822-1829.

Seabra, A., Serra, H., Seabra, A., Brito, J., Krustrup, P., Mota, J., et al. (2016b). Effects of a 6-month football intervention program on bone mass and physical fitness in overweight children. Spine Research, 2(1).

Skinner, A.C., Perrin, E.M., Moss, L.A., \& Skelton, J.A. (2015). Cardiometabolic risks and severity of obesity in children and young adults. New England Journal of Medicine, 373(14), 1307-1317.

Styne, D. M. (2001). Childhood and adolescent obesity: prevalence and significance. Pediatric Clinics of North America, 48(4), 823-854.

Tremblay, A., Simoneau, J.A., \& Bouchard, C. (1994). Impact of exercise intensity on body fatness and skeletal muscle metabolism. Metabolism, 43(7), 814-818.

Sundstrup, E., Jakobsen, M. D., Andersen, L. L., Andersen, T. R., Randers, M. B., Helge, J. W., et al. (2016). Positive effects of 1-year football and strength training on mechanical muscle function and functional capacity in elderly men. European Journal of Applied Physiology, 116(6), 1127-1138. 
Wang, G. Y., Pereira, B., \& Mota, J. (2005). Indoor physical education measured by heart rate monitor: a case study in Portugal. Journal of Sports Medicine and Physical Fitness, 45(2), 171.

Wei, M., Gibbons, L.W., Kampert, J.B., Nichaman, M.Z., \& Blair, S.N. (2000). Low cardiorespiratory fitness and physical inactivity as predictors of mortality in men with type 2 diabetes. Annals of Internal Medicine, 132(8), 605-611.

Wilmore, J., \& Costill, D. (1994). Physiology of exercise and sport. Human Kinetics, Champaign, IL

\section{EFEKTI REKREATIVNOG FUDBALA OD 12 NEDELJA I INTERVALNOG TRENINGA VISOKOG INTENZITETA (HIIT) NA FIZIČKU SPREMNOST KOD DECE SA PREKOMERNOM TEŽINOM}

Cilj ovog istraživanja bilo je odrediti efekte rekreativnog fudbala od 12 nedelja i intervalnog treninga visokog intenziteta (HIIT) na fizičku spremnost kod dece sa prekomernom težinom. Četrdeset i dva dečaka sa prekomernom težinom i gojaznošću uzrasta od 11 do 13 slučajno su podeljeni u tri grupe: HIIT grupa $(n=14)$, rekreativni fudbal $(n=14)$ i kontrolna grupa koja je pohađala redovno fizičko vaspitanje $(n=$ 14). Komponente fizičke spremnosti su merene na početku i nakon 12-nedeljnog treninga, u isto vreme $i$ pod sličnim uslovima, uključujući: countermovement jump (CMJ), sprint od 10 i 30m, fleksibilnost $i$ biohemijske parametre (leukociti, eritrociti, hemoglobin, glukoza, ukupni holesterol, trigliceridi). Grupa HIIT povećala je eksplozivnu snagu donjih ekstrema za 7,16\% (mala ES), dok je rekreativna fudbalska grupa zabeležila neznatno povećanje od 6,57\% (mala ES). HIIT je dovela do statistički značajnog povećanja $(p<0,05)$ u broju eritrocita u krvi $(8,90 \%)$. Rekreativni fudbalski program uticao je na poboljšanje rezultata kod varijable raznoženje u ležećem položaju $(6,21 \%)$ i broju eritrocita $(\uparrow 9,11 \%)$. Dvanaest nedelja rekreativnog fudbala $i$ HIIT-a mogu dovesti do pozitivnih promena u fizičkoj spremnosti, fleksibilnosti i biohemijskim parametrima gojazne dece i dece sa prekomernom težinom. $U$ poređenju sa eksperimentalnim grupama, kontrolna grupa je zabeležila manje promene u gore navedenim varijablama, što ukazuje na nedostatak intenziteta programa vežbanja u redovnim razredima fizičkog vaspitanja.

Ključne reči: rekreativni fudbal; intervalni trening; gojaznost; fitness 